\title{
TRIM33/RET Fusion Gene
}

National Cancer Institute

\section{Source}

National Cancer Institute. TRIM33/RET Fusion Gene. NCI Thesaurus. Code C99853.

A fusion gene that results from a chromosomal translocation $t(1 ; 10)(p 13 ; q 11)$ which fuses the 5' portion of the TRIM33 gene and the 3' portion of the RET gene. This rearrangement is associated with papillary thyroid carcinoma. 